\title{
Reading and relating: Digitally tracing human groupings in the illustrations of the Utrecht Psalter
}

\section{Stephanie Caskenette}

Department of Art History, College of Arts, University of Guelph, Guelph, ON Canada. Faculty supervisor: Dr. Dominic Marner.

For correspondence, please email: steph.cask@gmail.com.

\begin{abstract}
Within the illustrations of the ninth century Utrecht Psalter, groupings of multiple people with no imperative role in the narrative are found in large numbers. This inclusion is unique and with clear intention, and unlike other non-essential pictorial elements in the composition such as foliage or buildings, all of these figures are drawn to completion. As the images in the Utrecht Psalter show consistency in their measurements on the page, as well as through the scale of elements within the actual illustrations, direct comparisons can be made on how these figures are employed in the scene. By using digital applications to create a compositional overlay of all these groups, a concentration of figures on the left and right sides of the image is observed. This article suggests that such an arrangement provides a readable image, with human groups added in order to encourage engagement with the text of the Psalter and aid in remembering its messages.
\end{abstract}

Keywords: Utrecht Psalter; medieval literacy; manuscript illustration; image composition; digital humanities; artwork engagement

Reading, when its messages apply to ourselves, can touch us deeply. Certainly religious texts have achieved that quality like no other in history, and so it is important for contemporary scholars to observe how approaches in communicating Christian dogma developed in an age when literacy was not as widespread as it is today. Utrecht, University Library, Ms. 32, commonly known as the Utrecht Psalter, must have caught the eye of early ninth-century readers privileged enough to view it. It departs from customary characteristics of early medieval manuscripts in terms of size, script style, layout and most importantly illustration. As well, its pages contain dynamic pen drawings with figures in violent motion, not at all the decorative, posed miniatures one would have expected to find. Scholars have studied the exact measurements and proportions of Utrecht's illustrations in addition to their iconographical significance. In response, this article will focus on the compositions, or more specifically, their use of left and right pictorial spaces. I will first provide an overview of the relationship between Christianity and the codex form before engaging the reader. I will then recount my project that digitally maps the occurrences of groupings of nameless figures in the Utrecht Psalter and expand on its significance. Finally, I shall argue how my conclusions based on these results fit into a broader sphere of reading an image, as situated within Medieval European literacy and education. I aim to demonstrate how the Utrecht Psalter facilitates primary access to its messages by inserting linear illustrations that assumes a mnemonic role, creating a composition that draws viewers in and give importance to them within the scene.

Christianity is a religion of the book, not only to observers of its culture, but also in its own eyes. In medieval art, prophets and apostles are frequently depicted as holding a roll or codex, emphasizing the importance of books in understanding the word of God (Watson 2009). The weight of the written, sacred word in defining Christianity has held strong; although the act of recitation is essential to sermons, the written word has made an overwhelming impact, as it is perceived as a direct connection from God (Green 1998). The devotion towards a religious doctrine can manifest in physical book form, and the desire to distinguish the Bible from other texts may explain why fourth century Christians replaced the rolls of antiquity with the codex, which then became emblematic of Christian tradition of being of the Book. Through the codex came the practice of private reading, simplified by the division of chapters and paragraphs marked by numbers and margins. This convention was unfamiliar to the Torah, but enabled Christians to browse the Bible and find any passage, quickly (Grotans 2006). It is in this context that we find in the psalter. In the course of the eighth and ninth centuries, the Book of Psalms established itself as the only liturgical book that could also serve worshippers as a private prayer book. 
As the majority of early medieval Christians knew the psalms while growing up, it gained a pedagogical function as the text utilized to teach literacy (Innes 1998). Indeed, many educated people would know its words by heart upon completion of their schooling. Its importance is emphasized through the Latin psalteratus, considered synonymous with literatus throughout the medieval period (van der Horst et al. 1996).

Containing not only the Book of Psalms, but sixteen additional poetic writings, the Utrecht Psalter itself has been argued by scholars to not be a utilitarian text for monasteries for several reasons. In addition to the absence of other texts essential in the liturgy, monks reciting psalms in the choir could not have used it, as they would have been forced to frantically leaf through the pages in order to locate the right psalm to recite (van der Horst et al. 1996). Furthermore, numerous illustrations would hinder liturgical use. The patron of the Utrecht Psalter remains unknown, but by determining its function and deeming the illustrations as more than ornamental, we gain a deeper understanding of its audience and the messages they were intended to receive. Furthermore, we gain insights into the conditions of literacy, as well as its extent and growth in early medieval times.

It is quickly apparent why the Utrecht Psalter is considered to be one of the most illustrated surviving medieval manuscripts. Within its pages, scribes were provided generous drawing spaces to fill, and so a drawing extending over the full width of the writing space precedes each psalm and all sixteen canticles, contributing to its total of 166 illustrations. The sheer quantity of images indicates their importance and implies they are an essential element in experiencing Utrecht. In his writings on Utrecht, Koert van der Horst (1996) continually suggests the pleasure that the artists of the Utrecht Psalter must have experienced while working. It is unlikely that scribes methodically copied an earlier illustrated manuscript as the sketched style indicates a liveliness that cannot be slowly and carefully replicated stroke-for-stroke. Instead, the artists must have had a wellversed knowledge of the psalms they illustrated in order to carry out this style fluidly, without pausing and lifting their pens from the page to reference a Book of Psalms for instruction.

In studies of the Utrecht Psalter's illustrations, emphasis is placed on important Biblical figures in the image in order to better understand and appreciate the depicted scene. However, Utrecht's sketch-like style lends itself to an abundance of content within its illustrations; images do not contain a single figure, but several. Furthermore, the horizontal orientation of such scenes meant that simply including a single figure at a realistic scale would leave empty space within much of the image. In order to craft a realistic scene, plants, hills, architectural elements and most notably, groups of people were placed within illustrations. The role of these humans vary, as soldiers or members of the general populace, fitting the role of enemy or the just, but all look with unwavering focus towards the important actions in the scene, not only directing the viewer to focal points, but also reflecting the emotions that readers would experience. These figures, while modestly sketched, are uniform in depiction throughout the Utrecht Psalter and are always fully drawn, unlike the half-completed adjacent buildings or abstract foliage. Therefore, while they were not essential to the narrative of the psalms, their intentional placing differentiates them from mere background.

At the same time, despite their quantity and unique inclusion, these figures do not assume the central focus of their compositions. While Utrecht's illustrations are described as lively and containing dynamic movement, these groupings mimic the surrounding foliage and remain relatively static, blending into the scenery. I will describe these figures as extras, similar to the anonymous roles popularized in film or television, used to evoke a sense of realism to the scene. However, unlike film in which the viewer relates to main characters and protagonists, I would argue that the Utrecht reader is expected to project onto these human crowds, and not the holy figures. After all, to relate to such venerated beings could certainly be perceived as blasphemous. When a group looks up in awe at the hand of God, readers can insert themselves in the humble role of worshipper. While holy figures appear beyond reach through their indiscernible expression and spatially elevated position in the top register of the scene, the drawn humans convey emotion and a body language that the viewer can easily understand.

This immersive quality can be supported through two other elements of the Psalter. First, in the Book of Psalms, the audience is addressed with inclusive words such as "our", "we", "us", or "them", phrases that provide the reader a role within the narrative of the psalm and uniting them with the attributed writer David. Second, the vast, windswept landscapes evoke feelings of the ultimate sublimity, that being divine presence in the scene, which draws them into the illustration. While achieving modern fame through the 1674 French translation of the treatise On the Sublime, this text is attributed to Dionysius Longinus, a Greek rhetorician of the third century AD. Longinus writes that the influence of the sublime, experienced through the undomesticated immensity of the outdoors, had the ability to emotionally move the viewer, separating them from their physical body. In this theory of the sublime, the viewer is unrestricted and can act as participants in an overwhelming scene (Longinus et al. 1998). At first glance it seems farfetched to connect Longinus' Greek text to the suggested circumstances of Utrecht's creation in Reims during the Carolingian Renaissance. However, On the Sublime did have a readership, albeit perhaps limited, during the ninth century, evidenced by a transcribed copy presently housed in the National Library of France. While written in Greek and not the Latin of the Utrecht Psalter, some Franks were bilingual as a result of trading relations with Byzantium. 


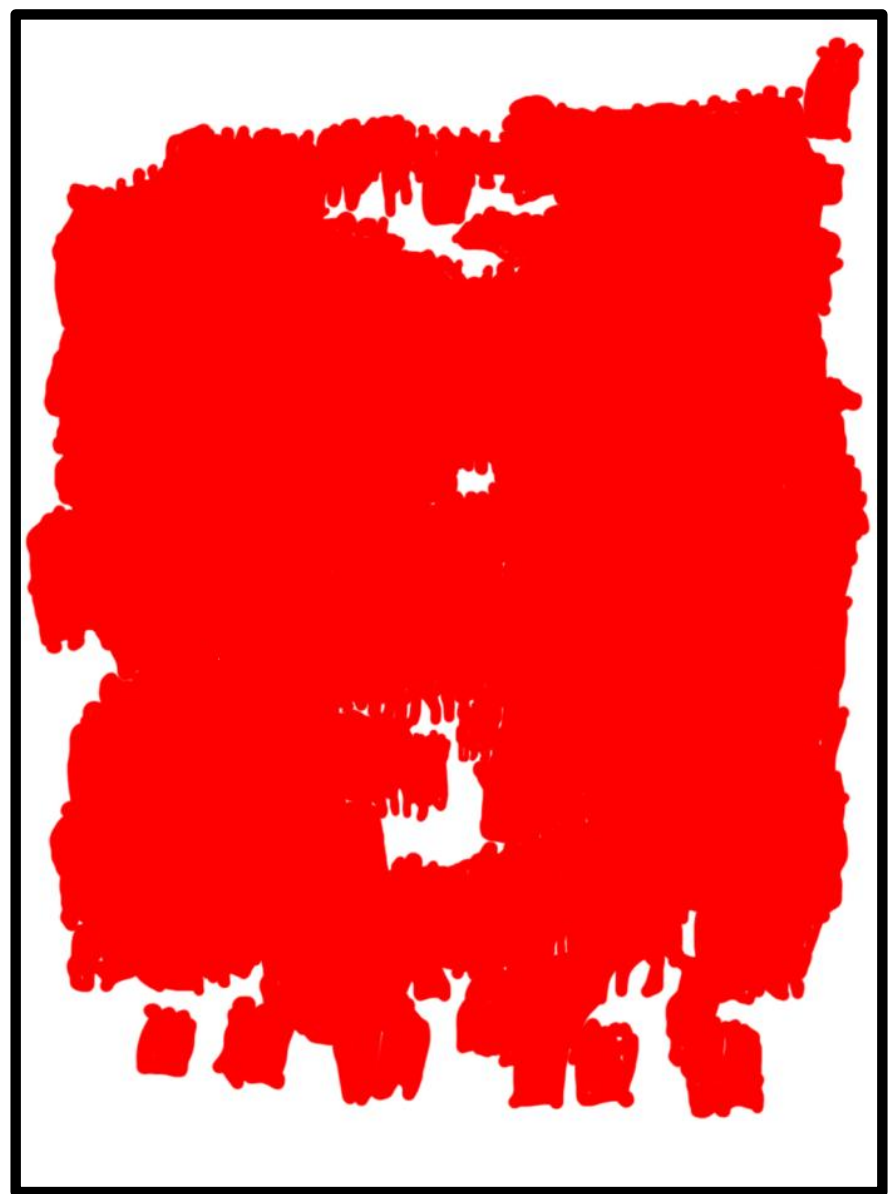

Figure 1. A superimposed image showing all occurences of groupings in the Utrecht Psalter illustrations, coloured in red with Adobe Photoshop CS6.

Diplomats travelled between Constantinople and the Frank Kingdom during the late eighth and early ninth centuries, frequently presenting books as gifts; a famous instance is a manuscript of the works by Pseudo-Dionysius the Areopagite in Greek, that were presented to Louis the Pious, heir to Charlemagne, by an embassy from Constantinople in 827 (van der Horst et al. 1996). This presents the possibility that other Greek philosophical works such as On the Sublime could have lingered in the minds of ninth century scholars and wealthy readers. Therefore, by contextualizing these holy words within a sublime landscape occupied by humans, the text provides a humanized and personal experience for the reader, suggesting a deeper immersion into the text and its messages.

Despite stylistic deviation from other early medieval manuscripts and the number of hands involved in its illustration, Utrecht adheres to its own sense of regularity in several ways. Within its 92 folios, dimensions of the writing space are nearly identical; excluding the full page illustrating the first psalm, each page is divided into three columns measuring 64 by $244 \mathrm{~mm}$ with intervals of $15 \mathrm{~mm}$ between each, within a space for 32 lines per column (van der Horst et

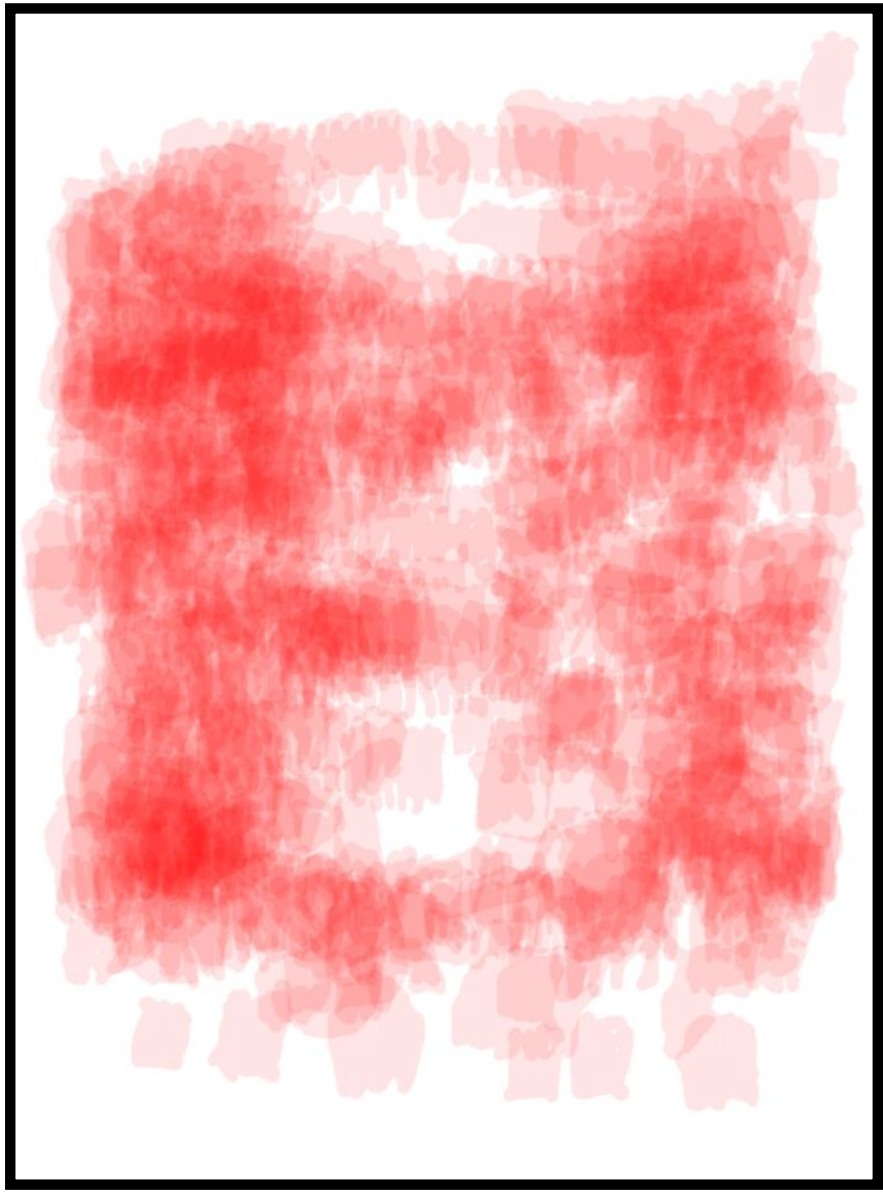

Figure 2. A superimposed image showing all occurences of groupings in the Utrecht Psalter illustrations, coloured in red with opacity of all layers reduced to $10 \%$ with Adobe Photoshop CS6.

al. 1996). Furthermore, there is consistency in the style and scale of the figures, suggesting that through a comparison of the spatial arrangement of these crowds, we can observe trends in their depiction in certain areas, or hot spots of the composition.

In comparing multiple pages of the Utrecht Psalter accurately, digital tools can aid in our analysis, a practice utilized in the examination of other medieval documents (Bell et al. 2013). My aim was to superimpose all 166 illustrations from the Psalter, appropriated from its digital facsimile on the Utrecht Library website (University Library Utrecht, n.d.). My method was simple but accurate, and aided by digital technology. Using Adobe Photoshop graphic software, I first compiled the page scans of Utrecht containing illustrations as separate layers in a single .PSD document. Next, pairing each illustration with a transparent layer, I coloured every occurrence of these crowds in red. In identifying these groupings, I adhered to a few guidelines. These groups had to contain more than three overlapping people. As well, holy figures such as Jesus and angels were excluded, in addition to those on horses, those who were slain, apparent leaders, or those performing important or 


\section{Digitally tracing human groupings in the illustrations of the Utrecht Psalter (Caskenette)}

deeply physical actions; these characters are pivotal to their scenes and do not assume the passive role of the aforementioned groupings in question.

When the layers are stacked at $100 \%$ opacity, we are provided with a compositional map showing where these crowds appear in the illustrations (Figure 1). However, this image provides additional information if the opacity of the layers are reduced to $10 \%$ (Figure 2). In other words, in any area of this image where the same true red colour is seen, crowds from ten different illustrations overlap; shades of red or pink represent less than ten overlapping groups. The resulting image shows that although there are no grossly unbalanced patterns, there are general areas that contain high concentrations of figures. While the length of the illustrations spans a sizable width, the standard location of groupings stand slightly off to the side, but never severely on the edge of the scene or in the middle. On a rudimentary level, we could assume that these extras are expected to flesh out the composition by framing the centre of the image, where a key figure would be placed as a focal point. However, there is a slightly stronger concentration of figures on the left side, which necessitates a deeper analysis.

The symbolism of left and right held significance to the Utrecht illustrators, as God is only pictured through his right hand, and never his left (University Library Utrecht n.d.). However, discussing the symbolism of left and right in the medieval era is problematic for several reasons. First, while many point to New Testament quotations that present left as bad and right as good, an equal number of Old Testament scriptures suggest otherwise (Genesis 48). This could be due to an association with the right-to-left reading of Hebrew (therefore moving towards the preferred left side). Second, scholars have offered conflicting views on societal attitudes towards left hands during the Medieval and Renaissance periods. Some have suggested that left connoted evil and witchcraft, while others point to a golden age for the lefthanded, citing the later cult of the left hand heralded by Lorenzo Medici (Hall 2008).

The largest complication is observed when referring to the right or left sides of an image. In pre-modern artworks, it was accepted that a scene was established in relation to its main figures, rather than to the viewer (Hall 2008). This is attributed to the belief that the figures in artwork are more significant than the viewer, and in certain respects independent to them, existing within the illustrated world that enraptures the viewer. In Utrecht we see this distinction between the human groups on the sidelines (to whom the viewer projects upon) and the holy figures that receive focus in the scene, reiterated through the psalter text itself, frequently attributed to David. The tradition of orientating images in relation to its main figures, rather than to the viewer is given support by the first learned treatise on heraldry, On Insignia and Coat of Arms by Bartolo da Sassoferrato. He envisioned someone simultaneously creating and inhabiting a piece of writing from the other side of the parchment (Cavallar and Degenring 1994, p 23):
In order that writing might affect our eyes, this action must begin on the right side of the writing, because that side is the source of motion and action. But the right side that faces us is, from our perspective, the left side, just as, if a person turns his face in my direction, his right side is on the left from my perspective.

Furthermore, Alcuin of York was the first to observe in the late eighth-century that the writing of holy men is dictated by God (Camille 1985). From God's perspective as situated across from the human scribe, guiding their pen, or among the clouds of the Utrecht as a disembodied hand, Christian writers would start on their left, which is what God perceived as the right side. With this logic, if our own writing is actually God's mirror writing, reversing our sense of left and right, symbologies of left and right can be unclear and ultimately reversible.

There is, however, another approach in which analyzing left and right can benefit our understanding of Utrecht. Art theorist and perceptual psychologist Rudolf Arnheim in Art and Visual Perception asserts, "a picture is 'read' from left to right" (Arnheim 1974, p 35-6). This inclination to 'read' an image can find foundation in a late sixth century letter from Pope Gregory the Great to the Bishop of Marseilles. The Bishop had destroyed the images in his church when he discovered a crowd worshipping their material form. Pope Gregory instead highlights the educative advantage of images (Duggan 1989, p 236):

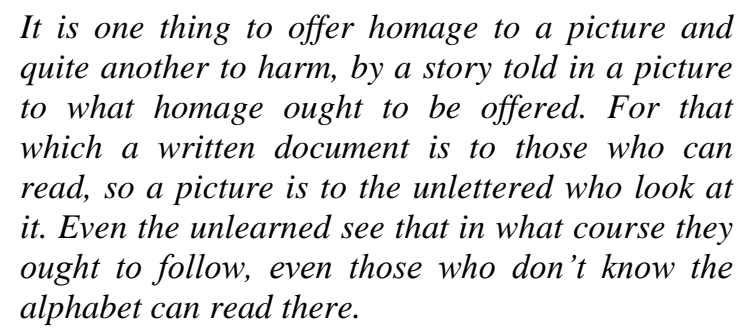

We can ultimately observe this visual system in medieval manuscripts that paired text with illustration. But by acknowledging that the viewer reads the image starting from their left, and not the illustrated figure's left, the implication of viewing medieval images, specifically those that contain clear narratives, shifts. The treatment of left and right then shows a change towards seeing left and right in relation to the viewer, assigning them an important role in interpreting the scene.

Furthermore, Arnheim believes that the left side of any picture is emphasized "by the viewer's identification with it" citing Grunewald's Crucifixion of the Isenheim Altarpiece (Arnheim 1974, p 35). He suggests that the figures of Mary and John the Evangelist are placed in the left side of the painting in order to satisfy the viewer's need to immediately empathize with the scene upon first glance. On the right, John the Baptist points to the aforementioned figures and Jesus on the cross to his left, redirecting stray gazes back to 
the important features of the painting. When this theory is applied to the composite image of the Utrecht Psalter, in which there is a higher concentration of figures on the left side, we can see that these groups could draw in the reader at the beginning of the scene, should they read the image from left to right. Art critic and historian James Hall suggests that we do not read an image in this way, for "in a sentence the first word or phrase is not necessarily more 'weighty' than the last" (Hall 2008, p 28). However, I would contend that the basic premises of sentence structure suggest otherwise, as the most important part of the sentence, the subject, tends to be followed by verbs and other secondary components. Perhaps then, we can interpret the grouping of figures being positioned not on a symbolic left side, but at a beginning of the composition. Therefore, by placing relatable human groupings at the beginning (or left side) of illustrations, viewers are provided with the most important information in the scene - their responsibility as observers and worshippers.

In examining how the Utrecht scribes visually transcribed the psalms, we can observe a narrative linearity. The drawing for Psalm 1 is the only illustration in the manuscript to fill an entire page and Koert van der Horst provides an excellent analysis, which I shall summarize (van der Horst 1996). Seated at the top left is the blessed man studying the law of the Lord through the day and night, with an angel behind him. Opposite to the depiction of the blessed man is the ungodly man seated on the chair of pestilence surrounded by soldiers and a demon entwined with writhing serpents. Two figures in the center, one of whom is the psalmist, are discussing the paths of these two contrasting scenes. In the lower register is a blooming tree planted near the running waters issuing from the urn of a classical river-god. To the right of the tree, a personified wind blows the wicked from the face of the earth like dust. Those at the front have already fallen and are being driven into hell by two demons armed with hooks and tridents, where a monstrous personification of Hades waits to take them.

What is important is the overarching left-to-right linearity of the scene when understood in conjunction with the psalm it illustrates. This page presents further linearity through the progression from the back of the picture plane, where the blessed man and ungodly man sit, to the front, where the wicked are forced into hell. While the illustrations offer a translation to understand the psalm, by delivering literal depictions of the words written, another function can be suggested. An important aspect is a possible mnemonic function of the drawings to aid the reader in learning all of the psalms by heart. As previously mentioned, the Book of Psalms was a useful resource for teaching literacy to ninth century readers, who would be likely to memorize its text. In true mnemonic fashion, the illustrations, while confusing when not in the context of the psalm, create a vivid mental picture for the viewer, who concurrently reads the psalm and the image from left to right. The narrative lingers in the memory of the reader, who can later recollect its exact wording. In the act of remembering the psalm, the reader can mentally traverse the sublime landscape of the psalm, first discovering an avatar in the groups of people on the left side of the page. As they navigate through the image, they can recall the imagery in the correct sequence. Despite the discourse that surrounded the adoration of images at the beginning of the ninth century, reflected by the aforementioned correspondence between Pope Gregory the Great and the Bishop of Marseilles, it was acknowledged that narrative depictions could serve a mnemonic function (Gibson-Wood 1987). By memorizing the psalm, readers would understand it and by understanding it, they would follow it and the overarching word of God.

Countless unanswered questions concerning the fundamental issues of the Utrecht Psalter remain, chiefly among them the identity of its patron. No simple conclusion can be made, however several remarks regarding my interpretations are in order. First, the Utrecht Psalter is unique through its numerous, stylistically united illustrations spanning the full width of their pages. Second, a digital compilation of its illustrations shows groupings of human figures concentrated on the left or right sides of the scene, with a slight emphasis on the left side. These figures are human, like their readers, and act as a device to draw the viewer into the scene so that they may better relate to the psalm, an arrangement extended by the sublime landscape background. Third, there is a tradition of reading an image from left to right during the Middle Ages. Lastly and most significantly, if the reader of the Utrecht Psalter is to view the image from left to right, then a higher concentration of the human crowds on the left side draws the reader into the scene at the beginning of the image. Any groupings on the right side, ending the scene, reinforce the role of the reader upon completion of reading the psalm by providing a parting impression. The inclusion of a drawn avatar for the reader becomes a mnemonic device, evoking a mental image that can be later recalled. The Utrecht Psalter's illustrations then achieve emotional and utilitarian functions by leaving a meaningful impression on the reader that will later aid in remembering the psalm illustrated. The utilization of these crowds alludes in a prophetic sense to the Renaissance humanism in assigning the reader an empathetic role through self-awareness in reading the scene. I am certainly not implying that any of my conclusions suggest an intentional act on the part of the scribes. But by determining the grouping's frequent placement on the right or left sides of the image plane and observing trends in their composition, if any, we can determine underlying views of humanity at the time, as well as the influences on approaches in which medieval audiences subconsciously read an image. 


\section{References}

Arnheim R. 1974. Art and visual perception: A psychology of the creative eye. Berkeley (CA): University of California Press. 518 p.

Bell P, Schlecht J, Ommer B. 2013. Nonverbal communication in medieval illustrations revisted by computer vision and art history. Visual Resources. 29: 26-37.

Camille M. 1985. Seeing and reading: Some visual implications of medieval literacy and illiteracy. Art History. 8: 26-49.

Cavallar O, Degenring S. 1994. A grammar of signs: Bartolo da Sassoferrato's tract on insignia and coats of arms. Berkeley (CA): Robbins Collection, University of California at Berkeley. $200 \mathrm{p}$.

Duggan LG. 1989. Was art really the "book of the illiterate"? Word and Image. 5(3): 227-251.

Hall J. 2008. The sinister side: How left-right symbolism shaped western art. Oxford (Eng): Oxford University Press. 304 p.
Longinus. 1998. On the sublime. In: Fyfe WH, Russel D, editors. The loeb classical library. Cambridge, (MA): Harvard University Press. p. 143-308.

Gibson-Wood C. 1987. The Utrecht Psalter and the art of memory. Revue d'Art Canadien/Canadian Art Review. 14: 9-15.

Green DH. 1994. Medieval listening and reading: The primary reception of German literature, 800-1300. Cambridge (Eng): Cambridge University Press. 483 p.

Grotans AA. 2006. Reading in medieval St. Gall. Cambridge (Eng): Cambridge University Press. 380 p.

Innes M. 1998. Memory, orality and literacy in an early medieval society. Past \& Present. 158: 9-10.

University Library Utrecht. n.d. Utrecht Psalter. Available at: http://bc.library.uu.nl/node/599

van der Horst K, Noel W, Wulfstefeld, WCM. The Utrecht Psalter in medieval art: Picturing the Psalms of David. Tuurdijk (Ned): HES. 284 p.

Watson R. 2009. Some non-textual use of books. In: Eliot S, Rose J, editors. A companion to the history of the book. Oxford (Eng): Wiley-Blackwell. p 480-492. 